\title{
Pomp and Circumstances: From Research, in Practice, for Students
}

\author{
Pompa y Circunstancias: DeSde la investigación, en la Práctica, para los \\ ESTUDIANTES
}

Pompe et Circonstanciels : de la Recherche, dans la pratidue, pour les ÉTUDIANTS

\author{
Jennifer Walsh Marr \\ M. A. Curriculum and Instruction, \\ Simon Fraser University, Canada. \\ Lecturer, Vantage College, University \\ of British Columbia, Vancouver, \\ Canada. \\ jennifer.walshmarr@ubc.ca \\ https://orcid. \\ org/0000-0002-1688-4707

\section{Jodie L. Martin} \\ Ph. D. Linguistics, University of \\ Adelaide, South Australia, Australia. \\ Lecturer, Vantage College, University \\ of British Columbia, Vancouver, \\ Canada. \\ jodie.martin@ubc.ca \\ https: //orcid. \\ org/0000-0002-2318-5656
}

\begin{abstract}
Circumstances are powerful grammatical tools for representing precision and specificity in the clause, and they add contextual factors necessary for nuanced disciplinary discourse. This type of detail expressed through circumstances is significant in academic discourse, yet it is often neglected in favor of attention to participants and processes. Drawing on our experiences teaching embedded, discipline-specific EAP to multilingual students at Vantage College at the University of British Columbia, we demonstrate how circumstances, and more broadly circumstantiation, generate crucial insights for both comprehension of complex academic materials and generation of student texts. We also show how circumstances are useful grammatical concepts pedagogically for working across the metafunctions and ranks in multiple ways: transitivity analyses of circumstance types within disciplinary texts highlight the relationship between their deployment and genre and stage variations. Additionally, probe questions provide a pedagogical lens to see detail and context in critical reading and writing. Circumstances also support organization by building Theme patterns through the strategic use of marked topical Themes, and convey interpersonal evaluation in academically appropriate ways. Connecting circumstances to broader circumstantial meanings provides a powerful mechanism for paraphrasing with grammatical metaphor. Finally, through our analyses and materials, we illustrate how explicit instruction in circumstances adds to students' linguistic and analytical repertoires and facilitates powerful insight for how circumstantial information contributes to academic discourse and knowledge-building.
\end{abstract}

Keywords: SFL; praxis; circumstances; EAP; circumstantiation.

\section{RÉSUMÉ}

Les circonstanciels sont les outils grammaticaux idéals pour représenter la précision et la spécificité au sein de la proposition puisqu'ils introduisent des facteurs contextuels qui contribuent à la production d'un discours disciplinaire nuancé. Ce type de détail, permis par l'ajout de circonstanciels, est important dans le discours académique. Cependant, ce dernier est souvent négligé au profit de l'analyse des participants et des processus. Notre expérience en tant qu'enseignantes d'anglais à but académique (EAP) aux étudiants multilingues à Vantage College à l'université de la Colombie Britannique, intégré et spécifique à chaque discipline universitaire,

Received: 2020-06-29 / Accepted: 2020-08-26 / Published: 2021-01-29

https://doi.org/10.17533/udea.ikala.v26n01a03 
nous a permis d'examiner la manière dont les circonstanciels, et, plus généralement, la circonstanciation, génèrent des informations cruciales lors de la compréhension de textes académiques complexes et la production d'écrits académiques par les étudiants. Force est de constater que les circonstanciels sont d'excellents outils grammaticaux au niveau pédagogique pour explorer les métafonctions et les rangs en plusieurs façons. Les analyses de transitivité des types de circonstanciels au sein des textes disciplinaires soulignent le lien étroit entre leur déploiement et les variations de genre et de scène. De plus, les questions exploratoires offrent une perspective pédagogique sur les détails et le contexte des écrits et lectures critiques. Les circonstanciels organisent le texte : ils participent à l'élaboration des structures thématiques et transmettent l'évaluation interpersonnelle de manière valorisée dans le contexte universitaire. Relier les circonstanciels à des significations circonstancielles plus larges fournit une méthode efficace pour paraphraser les métaphores grammaticales. Enfin, à travers les analyses et les contenus, nous montrons en quoi l'enseignement explicite des circonstanciels accroît le répertoire linguistique et analytique des étudiants tout en présentant à ces derniers les stratégies par lesquelles les informations circonstancielles contribuent au discours académique et au processus de développement des connaissances.

Mots-clés: LSF ; praxis; circonstancielles; anglais à but académique ; EAP ; circonstanciation.

\section{RESUMEN}

Las circunstancias son herramientas gramaticales poderosas para representar precisión y especificidad en la cláusula, pues agregan factores contextuales necesarios para matizar el discurso disciplinar matizado. Este tipo de detalle expresado a través de las circunstancias es de gran importancia en el discurso académico, pero a menudo se descuida por la atención prevalente para los participantes y los procesos. Basándonos en nuestras experiencias en la enseñanza de inglés que integra propósitos académicos a los estudiantes plurilingües en Vantage College a la universidad de la Columbia Británica propios de una disciplina, demostramos cómo las circunstancias y, en general, las circunstanciación generan indicios cruciales tanto para la comprensión de materiales académicos complejos como para la generación de textos de los estudiantes. Encontramos que las circunstancias son conceptos gramaticales útiles pedagógicamente para trabajar a través de las metafunciones y rangos de múltiples formas: los análisis de transitividad de los tipos de circunstancias dentro de los textos disciplinarios destacan la relación entre su despliegue, el género y las variaciones en las etapas de género. Además, las preguntas de prueba brindan una lente pedagógica para ver los detalles y el contexto en la lectura y escritura críticas. Las circunstancias también apoyan la organización del texto mediante la construcción de patrones temáticos a través del uso estratégico de Temas topicales marcados y expresan la evaluación interpersonal de manera académicamente apropiada. La conexión de circunstancias con significados circunstanciales más amplios proporciona un mecanismo poderoso para la paráfrasis con metáforas gramaticales. Finalmente, mediante nuestros análisis y materiales, demostramos cómo la instrucción explícita en circunstancias se suma a los repertorios lingüísticos y analíticos de los estudiantes y facilita una visión poderosa de cómo la información circunstancial contribuye al discurso académico y la construcción de conocimiento.

Palabras claves: LSF; lingüística sistémico-funcional; praxis; circumstances; EAP; inglés con fines académicos; circunstanciación. 


\section{Introduction: Pedagogically Speaking}

Academic writing requires the explicit articulation of contextual details which can be expressed through a range of grammatical resources. One important resource from the ideational metafunction within systemic functional linguistics (SFL) is circumstances. Circumstances are adverbials, prepositional phrases and a few noun groups which provide circumstantial or contextual information about the main activities of the clause (further description and examples are given in the subsequent section). Despite their utility and ubiquity, little attention is given to circumstances in either research literature or pedagogical materials for developing novice scholars' writing.

Circumstances are, by their very nature, peripheral; their presence is not necessary for grammaticality, and a key test for whether something is a ranking circumstance at the group level is whether it can be moved around or removed from the clause without fundamentally changing experiential meaning. Perhaps due to their peripheral role, circumstances are also often sidelined in references, research and pedagogical resources, and in the classroom, even while they are used to complement and enhance analyses of processes and participants, and genres and staging. This superficial treatment forms a challenge for anyone who wishes to know more about circumstances, especially for novice analysts turning to literature, whether as students learning about language for their studies, or as teachers developing their language knowledge for instruction. Additionally, the manifestation of circumstances in different forms is further complicated by different taxonomies (both within different SFL schools and as adaptations to different pedagogical contexts) and blurred boundaries between circumstances, participants, hypotactic (dependent) clauses, and circumstantial relational clauses. As teachers, particularly as English for Academic Purpose instructors teaching first year LX students, we have found circumstances to be more useful than the attention given to them in literature would suggest.
In this article, we argue that circumstances deserve more attention as productive analytical and pedagogical tools for scaffolding writing and critical reading in academic English courses. As instructors working with systemic functional grammar (SFG), we foreground circumstances in order to help our students understand and generate authentic disciplinary texts, full of complex and nuanced realizations, from our students' first year science and arts courses. From these authentic materials, we demonstrate how attention to circumstances elucidates the connection between the purpose of texts and the language features present in such texts. Furthermore, building on the concept of Dreyfus and Bennett (2017), we show that expanding attention to include broader realizations of circumstantial information within noun groups (as pre- and post-modifiers) and dependent clauses helps clarify challenges novices may have in identifying ranked circumstances at the group level. Casting an expanded view helps students recognize information they need to access and convey, and gives them access to language choices for the strategic deployment of that information, particularly in paraphrasing through grammatical metaphor (Walsh Marr, 2019). We therefore bring circumstances in from the periphery and center them for pedagogy.

\section{By definition: from the texts}

In order to focus on circumstances, it is necessary to clearly articulate what they are. In SFL, circumstances are one of the constituent elements of the Transitivity system, which identifies and analyzes the ideational components of texts. Analyses using this system shed light on patterns of representation in language. SFG identifies the constituents of ideational meaning according to their role in the clause; central to the clause is the process (what is happening or is); there is no (full) clause without a process. While participants are typically associated with processes, circumstances can be omitted without negative impact on the grammatical accuracy of a clause, as in the following example from a political science article by Lightfoot (2015): 
The Canadian Prime Minister apologized to Indigenous peoples.

$\begin{array}{ccc}\begin{array}{c}\text { The Canadian Prime } \\ \text { Minister }\end{array} & \text { apologized } & \begin{array}{c}\text { to Indigenous } \\ \text { peoples. }\end{array} \\ \text { Participant } & \text { Process } & \text { Participant }\end{array}$

While grammatically accurate, the information it provides lacks key contextualizing information; it begs the question "What for?" This is provided by a final circumstance in the original text: "for the Indian Residential School system."

The centrality of processes and their participants is mirrored in their simplicity; processes are congruently manifest as verbal groups and participants are typically noun groups, with attributive relational processes sometimes taking adjectives as attribute participants. As Lightfoot (2015) states, "In Indigenous peacemaking, the concept of respect is central" (p.24). Particularly in academic texts, participants may also be embedded clauses such as, "Canada's assistant deputy minister for Indian affairs offered what may have been the first governmental apology to Indigenous peoples" (p. 15). Circumstances, however, are realized by a range of grammatical categories that are peripheral to the process and participants. They most commonly manifest as prepositional phrases but also as adverbials and occasionally noun groups (Table 1). Halliday and Matthiessen (1999, p. 63) describe adverbs as Type 1 or "simple circumstances," and observe they most commonly represent quality, while prepositional phrases are labelled as Type 2 or "macro circumstances."
Prepositional phrases combine a preposition with a noun group (which can itself be variously expanded). While Halliday and Matthiessen do not include them, pedagogical texts (Derewianka, 2011) include a selection of noun groups that can be used as circumstances of time and place.

Circumstances are an important resource because they can provide a wealth of detail. They can articulate a range of nuanced meanings - Halliday and Matthiessen (2014, pp. 313-328) detail nine types with 21 sub-types.

Table 2, based on an elaborated table by J. R. Martin et al. (2010, pp. 101-102), presents examples of every sub-type taken from three first-year history, geography and political science texts (Andrea \& Overfield, 2012; Knox \& Marston, 2013; Young, 2013) that our students must read. These types can be identified with probe questions to determine and categorize the type of information they describe; pedagogically they are very useful in critically interrogating texts and elaborating meaning. Significant relevant information would be lost if they were omitted from discussion, analysis and representation.

In order to truly grasp the use of circumstances, one must be able to grasp an overlapping trifunctional perspective, which is challenging for any apprentice grammarian. Nevertheless, circumstance analysis is often used to augment the conclusions drawn about processes, participants, and genres by highlighting the type of information valued in the discipline. It is therefore helpful to make explicit

Table 1 Forms of Circumstances

\begin{tabular}{ll}
\hline \multicolumn{1}{c}{ Form } & \multicolumn{1}{c}{ Example (relevant Circumstance underlined) } \\
\hline $\begin{array}{l}\text { Prepositional phrases } \\
\text { (typically preposition + noun group) }\end{array}$ & $\begin{array}{l}\text { In } 1997 \text { and } 1998, \text { the kings of Norway and Sweden each offered formal apologies to the Sámi } \\
\text { people for years of widespread discrimination and injustices committed against them... } \\
\text { Adverbials }\end{array}$ \\
$\begin{array}{l}\text { In this statement, Harper acknowledged that "very young children were often forcibly removed } \\
\text { from their homes... inadequately fed, clothed and housed." }\end{array}$ \\
$\begin{array}{l}\text { The next year, the United States Senate passed a resolution apologizing for past policies of the } \\
\text { U.S. government toward Native peoples. }\end{array}$ \\
\hline
\end{tabular}


Table 2 Circumstance Types (based on J. R. Martin et al., 2010, pp. 101-102)

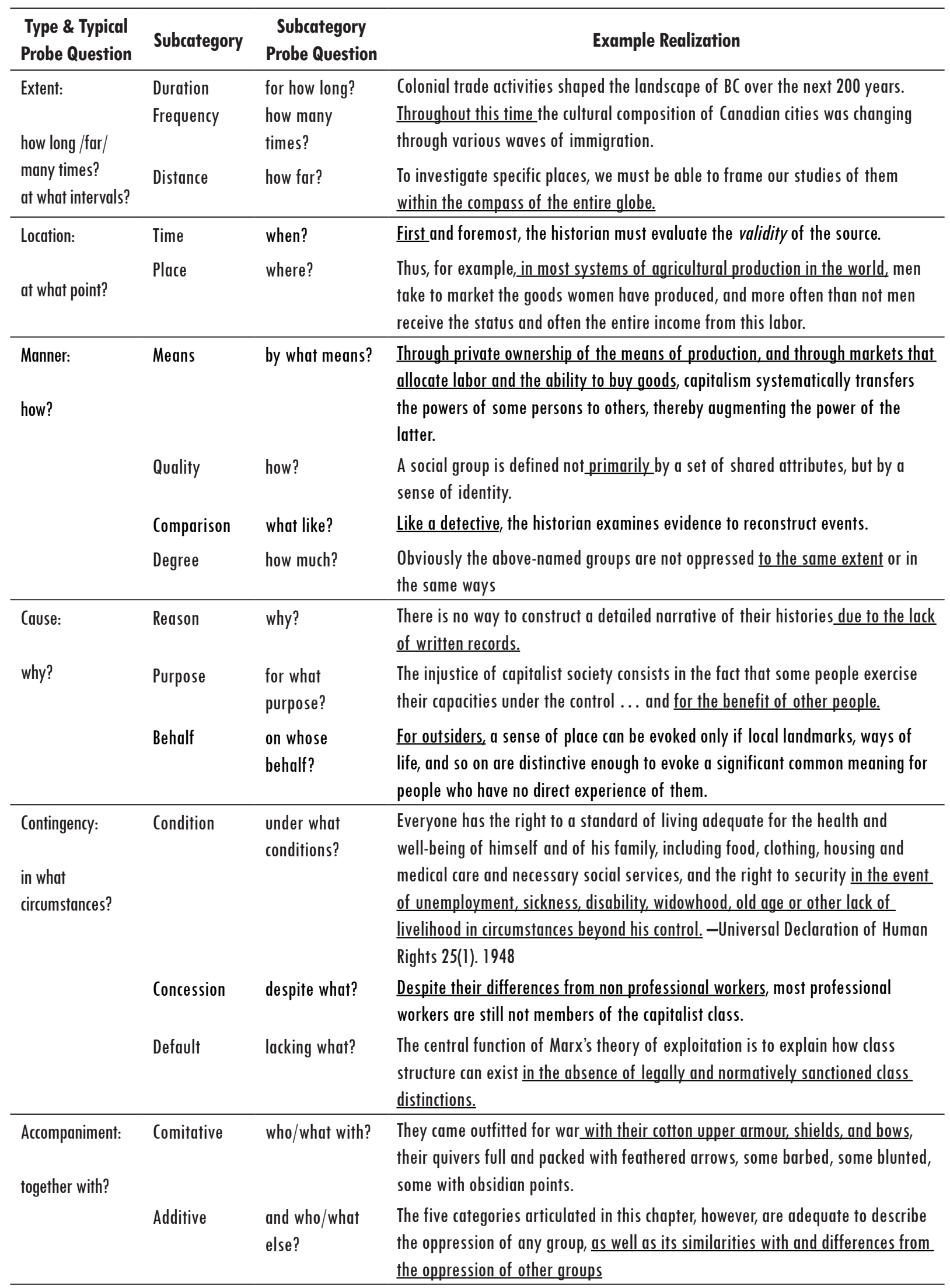


Table 2 Circumstance Types (based on J. R. Martin et al., 2010, pp. 101-102) (Cont.)

\begin{tabular}{llll}
\hline $\begin{array}{l}\text { Type \& Typical } \\
\text { Probe Question }\end{array}$ & Subcategory & $\begin{array}{c}\text { Subcategory } \\
\text { Probe Question }\end{array}$ & \multicolumn{1}{c}{ Example Realization } \\
\hline Role: & Guise & what as? & $\begin{array}{l}\text { I offer below an explication of five faces of oppression as a useful set of } \\
\text { categories and distinctions... }\end{array}$ \\
& Product & what into? & $\begin{array}{l}\text { All mineral wealth, e.g. ore, oil, coal, salt, etc., as well as all forests and waters } \\
\text { of state importance, shall pass into the exclusive use of the state. }\end{array}$ \\
\hline Matter: & & $\begin{array}{l}\text { Human geography reveals how and why geographical relationships matter in } \\
\text { terms of cause and effect in relation to economic, social, cultural and political }\end{array}$ \\
what about? & phenomena. \\
\hline Angle: & Source & says who? & $\begin{array}{l}\text { In this process of the transfer of powers, according to Macpherson, the capitalist } \\
\text { class acquires and maintains an ability to extract benefits from workers. }\end{array}$ \\
whose angle? & Viewpoint & $\begin{array}{l}\text { from whose } \\
\text { An understanding of geography is important both from an intellectual point of }\end{array}$ \\
& & perspective? & $\begin{array}{l}\text { view that is, understanding the world around us) and a practical point of view } \\
\text { (for example, contributing to environmental quality, human rights, social justice, }\end{array}$ \\
& & business efficiency, political analysis, and government policymaking). \\
\hline
\end{tabular}

how circumstances are useful, particularly for disciplinary academic writing. Circumstantial elements also play a role in other metafunctions: in the textual metafunction, it is vital to identify fronted circumstances as marked topical Themes which help build information flow through Theme patterns and emphasis (Eggins, 2004); in the interpersonal metafunction, we propose that certain circumstances, operating as circumstantial adjuncts, can be used to enable students to critically read for perspective and source, and to understand how dialogic space is expanded or contracted (Liardét, 2018). Thus, the same elements can be circumstances, fronted topical Themes, and circumstantial adjuncts, just seen through the different lens of each metafunction. As such, they are useful for demonstrating disciplinary knowledge and genre expectations.

\section{On the Periphery of the Clause and SFL}

Having exemplified circumstances from our class texts, here we summarize the relative presence and absence of descriptions of circumstances in literature. While neglecting circumstances may seem relatively benign, we argue that the dearth of resources limits their incorporation into learning materials and, by extension, supporting students' meaning making.

Circumstances are described in grammar as existing in orbit of the nuclear center formed by processes and participants. Halliday and Matthiessen (2014) expressly describe the hierarchy of constituents in transitivity:

The process is the most central element in the configuration. Participants are close to the centre; they are directly involved in the process, bring about its occurrence or being affected by it in some way. [...] Circumstantial elements augment this centre in some way - temporally, spatially, causally, and so on; but their status in the configuration is more peripheral and, unlike participants, they are not directly involved in the process [emphasis added]. (p. 221)

Elaboration of the augmentation Halliday and Matthiessen describe is largely elided from references, from research, and from pedagogical materials. For definitions of circumstances, the most comprehensive overview is given in the Introduction to Functional Grammar (IFG) (Halliday \& Matthiessen, 2014), with J. R. Martin, Matthiessen and Painter (2010) usefully providing exercises and troubleshooting in reference to the third edition of IFG (Halliday \& Matthiessen, 
2004). Eggins (2004) provides two examples for each type, while Butt et al. (2000) focus on form, leaving functional type and contributions to field to a relatively common-sense realm of understanding.

Books which aim to present a simple and accessible introduction to SFG may omit circumstances entirely (Banks, 2019; Thompson, 2014). Nonetheless, such texts draw on the analysis of circumstances to elucidate other transitivity examples, focusing on processes (verb groups) and participants (noun groups), or their presence in other metafunctions, such as marked topical Themes (textual metafunction) or circumstantial adjuncts (interpersonal metafunction).

Explorations of circumstance use that do exist create important insights for both analysts and teachers; Dreyfus and Jones (2008) propose more delicate categories for circumstances of Location, and Chen (2016) shows how circumstances of projection-specifically Angle-are realized differently in Chinese and English. Dreyfus and Bennett (2017) make a case for expanding the understanding of circumstantiation, and Dreyfus and Hao (2020) argue for a multistratal perspective of circumstantial meaning. More in-depth discussions of form, function, and use are included in Derewianka (2011) and in the companion workbook by Humphrey et al. (2012); significantly, these texts are intended for primary and high school teachers, making clear connections between developmental use of circumstances and their correlation with genres. Drawing on these materials, we were inspired to take a closer look at how we might use circumstances pedagogically in an Academic English context, and discovered a greater resource than anticipated for disciplinary language building.

\section{Ranked Circumstances: By Metafunction}

A fundamental attribute of circumstances is that they can provide a range of meanings with a degree of flexibility in both form and functions. This section presents a series of applications of circumstances according to metafunction, from a variety of genres and disciplinary fields, which are used to inform our teaching materials.

\section{Ideational Instantiations: On Purpose}

From an ideational perspective, there are two key pedagogical messages about circumstance types. The first and most common is that certain fields or genres or stages use particular types of circumstances to achieve their purposes. This focuses on frequent usage and therefore often results in an exclusive emphasis on the most common circumstance types: Location (time and place) and Manner. Such circumstances can be relatively accessible to the novice learner, answering the distinct probe questions of when, where and how. Yet, even these few categories cover such a breadth of variation that further analytical distinctions have been proposed (Dreyfus \& Jones, 2008). This focus is fruitful and likely plays a stronger role in classrooms than may be represented in textbooks. The second pedagogical message is often elided: some circumstance types are rare, both in terms of their usage within texts (once or twice per text) and in terms of the texts in which they get used (fewer genres, certain stages, or particularly niche topics). However, for the apprentice academic writer, insight into how and when to appropriately and strategically deploy these subtypes can be powerful.

\section{Across disciplines: Connecting Features to Purpose}

The breadth of circumstance types may seem exhaustive and even esoteric at first glance, with nuanced patterns in usage. These patterns tend to be in two directions: the distinct type (for example, circumstances of Location: place as compared to circumstances of Location: time) or of semantic meanings within type (for example the difference in circumstances of Location between geographic and metaphorical places, or specific and relative time). Identifying these patterns with students helps to elucidate the purpose and emphasis of a text.

An example of this distinction comes from a reading from political science in which official state 
apologies to First Nations peoples in Canada and Australia are evaluated against James' (2008) framework of authenticity (Lightfoot, 2015). In our language course, we analyze the linguistic features that are valued in disciplinary readings such as this to foster students' participation in academic discourse. In the two excerpts examined closely in this particular lesson, we highlight the frequency, type and position of ranked circumstances within the clause. In terms of type, the circumstances of Location: time build the chronological order of the recount used to introduce the apologies, while examples of Location: place, Manner: means, Accompaniment: comitative, and Cause: behalf situate the apologies in their national and historical contexts. These examples support the excerpt's function to inform the reader of what happened, without making overt judgements about their merit. The relevance of position will be discussed in the next section on textual instantiations.

On February 13, 2008, [Location: time] Australia's newly elected Labor Prime Minister Kevin Rudd opened his first session of Parliament with his government's first official act [Manner: means]. With crowds gathered outside and his image broadcast live on television throughout the country [Accompaniment: comitative], the prime minister rose and delivered an official apology on behalf of the government of Australia to the Stolen Generations-the Aboriginal children that had been removed from their homes and families under a century-long forced assimilation program [Cause: behalf]. Several months later, on June 11, 2008 [Location: time], the Conservative prime minister of Canada, Stephen Harper, stood before Parliament [Location: place] in the House of Commons [Location: place] and delivered a new "official statement of apology" that he said was offered to Aboriginal survivors of Canada's Residential School system "on behalf of the government of Canada and all Canadians [Cause: behalf]”

After describing when and why apologies were made, Lightfoot then engages in evaluating the authenticity of those apologies. She does this both by explicitly discussing James' (2008) criteria, and also implicitly with an expanded repertoire of circumstances. In the excerpt below we see more examples of Location: time and place, Cause: reason, and especially Manner: quality as it shifts from describing when and where this particular apology occurred to evaluating the manner in which it was delivered.

Canada's 1998 "Statement of Reconciliation" was read by Jane Stewart, the Minister of Indian and Northern Affairs, during a lunchtime ceremony [Location: time] in a government meeting room in Ottawa [Location: place], in response to the final report issued by the Royal Commission on Aboriginal Peoples [Cause: reason]. This statement of reconciliation sought to close the book on the historical legacy of Residential Schools, and situated that policy within a wider framework of "racial and cultural superiority" that "led to a suppression of Aboriginal culture and values." The statement did articulate, albeit briefly [Manner: quality] and in guarded language [Manner: quality], the historic harms of Residential Schools. The statement explicitly [Manner: quality] mentioned the legacy of abuse at Residential Schools and situated such abuse within a larger pattern of colonialism [Location: place], specifically acknowledging a number of historical events, yet neglected to use the words "apology" or "sorry" anywhere in the text. (Lightfoot, 2015, p. 30)

In the excerpt above, we also see a metaphorical use of Location: place; instead of being a physical location, the phrase "within a larger pattern of colonialism" locates this piece of history within a political analysis of the context.

Similarly, in procedural writing, circumstances play an important role in achieving their purpose. Circumstances were found to form the majority of the word count and provide fundamental contextual detail and precision, in both lab reports for physics and chemistry, and research reports for discourse analysis. A focus on circumstances was useful, for example, in teaching how to write chemistry procedures; these include particular circumstance types, such as exact Locations, Extent, and Manner: means, as well as conditional circumstances to specify hazards, which were then excluded from the observation stage following the experiment. Drawing attention to these different categories of information and their different use in different genres associated with lab work gave students linguistic tools to tackle scientific processes. 


\section{Exceptional Usage: In Extraordinary Circumstances}

While an analysis of most common types of circumstances enables powerful description, we have found that most of our students' assigned readings include at least a few of the rarer types of circumstance, and certain genres of writing may use them as well. If we omit these from instruction, we risk omitting details which may support a text achieving its purpose.

As an example of rarer types, we have found circumstances of Role in three distinct fields: political science, linguistics and chemistry. Firstly, we return to Lightfoot's (2015) analysis of a Canadian apology for the treatment of Indigenous peoples. In it, we have a condensed version of a recount moving to evaluation; it begins with circumstances (both fronted and clause-final) of Location: time and Location: place, but then deploys Manner: quality and the uncommon Role: guise to make clear the manner and mechanism for colonization; she uses this rare circumstance to make explicit the connection between the stated purpose of the Indian Residential School system to “...continue until there is not a single Indian in Canada that has not been absorbed into the body politic" (Scott, 1920) and its abusive practices to do so:

On June 11, 2008 [Location: time], a much more public and formal apology was issued to the former students of Canada's Indian Residential Schools by Prime Minister Stephen Harper in the House of Commons [Location: place]. In this apology [Location: place] Harper stated, "The treatment of children in Indian residential schools is a sad chapter in our history." In this statement [Location: place], Harper acknowledged that "very young children were often forcibly [Manner: quality] removed from their homes ... inadequately [Manner: quality] fed, clothed and housed." He also noted that, as a tool of assimilation [Role: guise], the schools prohibited the speaking of Native languages and the practice of Native cultures.

Similarly, circumstances were significantly used in a linguistics procedural text on science communication, constituting over $50 \%$ of the word count of a single paragraph on data selection in a methods section. The circumstance of Role was important to achieving the purpose of the paragraph and was readily incorporated into students' own methods sections.

As this is a leading, peer-reviewed journal in the discipline of Computer Science, its articles can be considered as representative, quality articles of this field [Role: guise]. (O’Leary, 2019)

Finally, in chemistry, discussion of the circumstances demonstrates how they help texts achieve their purpose. In the excerpt below, the circumstances give methodological details about the experimental processes, and the final Roles of both product and guise concisely present the results of the experiment.

The combined organic extracts were dried over anhydrous magnesium sulfate [Location: place], filtered and evaporated to dryness [Role: product] to give eugenol as a light yellow oil $(0.97 \mathrm{~g}, 5.9 \mathrm{mmol})$ [Role: guise].

(The Learning Centre, The University of Sydney, 2012)

These few instances of circumstances of Role demonstrate exactly the affordances of using a full taxonomy of circumstance types for pedagogical purposes, rather than a simplified or abbreviated one. Ignoring or glossing over such uncommon yet powerful examples would miss opportunities to fully engage with and appreciate their critical meanings and logic. In the arts in particular, this risks whitewashing history, as it can be all too easy to gloss over the roles, perspectives and contextual factors that situate uncomfortable histories. By working with a full taxonomy of circumstances and their probe questions, we enable critical reading to not only rely on implicit cultural knowledge but instead scaffold a grammatical basis for tackling texts. This provides the opportunity to draw attention to a meaning which elevates the writing of the discipline by providing necessary detail and analytical lenses.

\section{Textual Instantiations: For Organization and Focus}

One of the key criteria for identifying a ranking circumstance is whether it can be moved around the clause without changing the ideational meaning. In the following excerpts from history and sociology 
articles analyzed in our coursework, the underlined circumstances occur either within the verbal group or in clause-final position. Consider, however, how they might be moved between either of these positions or even to the front of the clause:

So far, most of the running against Chief Justice Allan McEachern's findings in Delgamuukw v. B.C. has been made by native people and anthropologists. Both groups have, quite rightly, objected to the denigration of native cultures, to the fact that oral testimony was first admitted then dismissed, and to the assertion that anthropologists were largely unreliable witnesses. Lawyers have also commented on the case in print, and will do so in more detail when the argument is rejoined in the British Columbia Court of Appeal. Without wishing to diminish the force of any of these criticisms, I want to look at the judgment from the point of view of an historian [Angle: viewpoint]. McEachern's "Reasons for Judgment" is a "book" that also ought to be reviewed as a piece of historical writing in its historio-graphical context. (Fisher, 1992, p.43)

We examine the Idle No More movement within the framework of a relational understanding of social inclusion [Location: place: (metaphoric) location], drawing from both western social theory and Indigenous perspectives in order to take into account relations of power, inequality and discourse as advanced through a relational understanding of social inclusion and exclusion. (Wotherspoon \& Hansen, 2013, pp. 22-23)

Thematically, the excerpts build the field of expert analysis and embodied experience through fronting Sayers, Verbiage, and Senser participants (native people, anthropologists, lawyers, the authors and their nominalized findings). It uses circumstances to merely "illuminate" the process from the periphery and introduce new perspectives and frameworks in the rheme to be further developed in the text.

In a Theme analysis, fronted circumstances are identified as marked topical Themes: marked because they are atypical, and topical because they often signal key information about the topic of the clause. In the context of academic writing, the major considerations are choosing what to emphasize in Theme position, and building or shifting focus through Theme patterns. Fronting or thematizing circumstances does change textual meanings by providing greater emphasis through the new point ofdeparture for the clause as "marked [circumstantial] Themes indicate that these clauses, together, are doing something significantly different from immediately preceding clauses" (Eggins, 2004 , p. 320). As such, it is an extremely practicable tool for students and particularly language learners for building cohesion.

In the examples above, moving these circumstances to Theme position would shift the focus to these analytical lenses. This, in turn, might risk limiting engagement and discussion prematurely if the reader is put off by the prominence of such a lens. In the next excerpt, fronting the circumstance serves that very purpose of deliberately framing a (limited) perspective. It articulates a 'mainstream perspective' as a distinct position no longer to be assumed and left unsaid, and in contrast with the subsequent thematized participant and their lived experience:

From mainstream perspectives, the era of colonialism may have ended between the late nineteenth and mid-twentieth centuries, when former British colonies such as Canada, New Zealand and Australia were granted independence. Indigenous peoples, though, remained under colonial rule. (Wotherspoon \& Hansen, 2013, pp. 28-29)

At both a clause level and at larger staging levels, patterns of marked topical Themes are fundamental in helping texts achieve their purposes (Humphrey et al., 2012; Eggins, 2004). In the chronological recount from Lightfoot (2015) discussed earlier, the fronted circumstances of Location: time set up the chronological sequence, thus providing a linear flow through disparate events separated by geographic and political location. In that descriptive section, the fronted circumstances provide emphasis on the time. In comparison, the analytical section includes more circumstances near the process and at the end of the clause, shifting Thematic meaning to the participants and thus returning circumstances to their peripheral role in 'augmenting' the process. 
While fronted circumstances of Location are particularly clear in historical and geographic texts, highlighting their position in the clause is also useful for other types, as well as highlighting when not to front them. Chen (2016) observes through corpus analysis that circumstances of Angle: source are usually Thematized in Chinese, while in English they are equally likely to be in final position in the clause as at the front. As Chinese-speaking students form a significant proportion of our students, this insight is useful and valuable in our teaching context by highlighting where interlingual interference could take place. Having access to both the experiential meaning of 'Angle: source' and the textual meaning of 'marked topical Theme' provides a metalanguage for encouraging students to make more informed decisions of when and how to use these particular circumstances.

\section{Interpersonal Instantiations: In Relation to One Another}

Circumstances can also play a role in the interpersonal metafunction: while at the lexicogrammatical stratum we could consider their role as circumstantial adjuncts in the Mood system, we wish to shift to the discourse semantics stratum, and in particular focus on the Appraisal system (J. R. Martin \& White, 2005). Here, interpersonal relations can operate across constituent categories, drawing meaningful connections. At the same time, this can make them difficult to teach to novice writers, as any and all grammatical categories can be considered. We propose that focusing on relevant circumstantial types can provide an accessible starting point for students to enhance critical reading and writing by adding an interpersonal lens to the established experiential meanings. Certain circumstances have distinct interpersonal meanings and thus provide a point of focus for teaching; here we show briefly how circumstances are used in evaluation (Attitude and Graduation) and in expanding or contracting the dialogic space (Engagement).

Interrogating the circumstance Angle: viewpoint can demonstrate critical perspectives; see, for example, the following excerpt and subsequent explanation to students from our teaching materials:

In 1982, Canada ratified its new constitution. In Section 35(1) it provides constitutional protection for "any existing Aboriginal right." However, from an indigenous perspective, the constitutional protection, while valuable, does not go far enough since it only protects the rights secured up until that point in history (Lightfoot, 2010, p. 100).

The explicit articulation of perspective highlights Indigenous peoples' opinion that the Canadian constitution's protection for "any existing Aboriginal right" is insufficient, in contrast to an assumption that the Canadian constitution does enough to secure title to traditional lands (Walsh Marr, 2020).

Such teaching materials highlight these circumstances to draw students' attention to how authors position themselves and their claims, how they attempt to establish their authority and alignment with the reader, and any assumptions about their reader. Specifically relevant to a discussion of the circumstance Angle: source, J.R. Martin and White (2005) state,

it is possible for attributed material to be implicated in the alignment strategies at work in the text. These are mechanisms by which the reader is covertly positioned to regard the attributed material as either highly credible and warrantable, or alternatively, as dubious and unreliable. High credibility can be implied via the use of sources who have high status in the field... or as Hood 2004 has observed, via the assembling of a multiplicity of sources in support of the attributed material. (p. 116)

Contextualized examples such as the following demonstrate how circumstances can differentiate the source of authority within a text; we task students with deciding whether these indicate alignment and solidarity (pp. 114-115), or acknowledge but distance (p. 113) the author from the source:

Nevertheless, it [UNDRIP] does now form part of the international human rights consensus, and according to a UN press release, represents a "major step forward towards the promotion and protection of human rights and fundamental freedoms for all ... [through] .. . the General Assembly's important role in setting international standards." (Lightfoot, 2010, pp. 86-87) 
The Indian Act identifies those Indians with "status" as distinct from those without it. According to the Indian Act, only status Indians are eligible for benefits or exemption from taxation. Once status is lost, it cannot be regained. Status can only be retained by living on a reserve. The Act is widely criticized by First Nations and Inuit, but especially by Métis and urban Aboriginal peoples. (Lightfoot, 2010, p.100)

The analysis of underlying positioning achieved by certain circumstances extends to Accompaniment: comitative:

Without legal authority or foundation, in the 1880's Canada instituted a "pass system" that was intended to confine First Nations people to their reserves. (TRC, 2015, p. 1)

It further extends to Location: place to situate a statement or analysis:

New Zealand is willing to make legal and policy moves in indigenous rights within the framework of the Doctrine of Discovery interpretation of reconciliation, but it always remains solidly within this framework

The examples above answer the circumstance probe questions (in order): From what perspective? According to whom? With what (authority)? Where (within what framework/ideology)? They are critical questions to ask, and can also serve as a checklist for students to ask of texts that don't explicitly articulate such contextual information, allowing them to uncover missing information, assumptions and/or biases. This useful access point provides structures for strategic integration into writing and gives access to interpersonal meanings in addition to the ideational ones.

As we have demonstrated, circumstances provide a wealth of information, both in their frequency and commonality, and in their rarity and exceptionality. Accessing this information provides important insight for students in engaging with critical reading, as well as important strategies for adding detail to writing. Circumstances also provide an important tool for building flow in a text through their use as marked topical Themes,

both by connecting clauses to previous information in a text as well as by strategically choosing what to emphasize in Theme position. Finally, circumstances can also provide a lens for examining interpersonal positioning by providing questions for identifying perspectives as well as emphasizing how dialogic space may be expanded or contracted. Thus far, however, we have only considered ranked circumstances; there is a broader range of circumstantial meaning that can be used to enhance teaching.

\section{Circumstantial Information: For Clarity of Meaning, Not Complexity of Form}

Dreyfus and Bennett's (2017) extended discussion of circumstantial information complicates yet enhances our comprehension of circumstances. They expand the discussion of circumstantial information at different strata of language, moving beyond the formal manifestations of circumstances to downranked prepositional phrases functioning as post-modifications within noun groups, and scaling up to dependent clauses. This movement of information across formal grammatical constituents is a key component of introducing grammatical metaphor to novice writers.

The specific form of grammatical metaphor known as nominalization is an important feature of scholarly texts (Liardét, 2018). Nominalization shifts processes into nouns, serving to 'pack up' information into denser lexical bundles. Nominalized as a phenomenon, a process can now not only be held in a more stable form, it can be further described and analyzed with pre- and postmodification. Prepositional phrases previously functioning as circumstances around a process might now become part of the nominalization, often as a pre-modifying adjective, classifying noun, or post-modifying prepositional phrase as shown below:

From an Indigenous perspective, people relate to land in an intimate way.

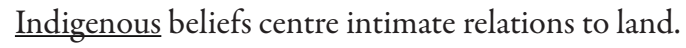


The beliefs of Indigenous people centre intimate relations to land.

Highlighting grammatical metaphor as a phenomenon allows for analysis of language features used to construct meaning; close attention to how ideational meaning can be represented congruently or metaphorically across formal grammatical categories facilitates enhanced paraphrasing skills (Walsh Marr, 2019). Grammatical metaphor is also an aspect of Dreyfus and Bennett's (2017) argument for the recognition of circumstantial information, contextual information that can be packed up metaphorically into pre- and post-modifications within noun groups, or expanded into dependent clauses. They focus on how circumstantial meaning manifests across a spectrum of possible instantiations, expanding the range of units of analysis. This allows us to access broader meanings, regardless of their grammatical categories, and to deploy the probe questions to interrogate context.

For example, from Lightfoot (2015), we show our students how circumstantial information can manifest across various forms (followed by the relevant probe questions):

- Post-modifiers in noun groups: “...a lunchtime ceremony in a government meeting room in Ottawa" (Where?)

- Pre-modifiers in noun groups: "The 1998 Canadian "apology"..." (When? Who for?)

- Dependent clauses: “... because an apology has been offered." (Why?)

- Reduced/Non-finite clauses: "Given the notable recent increase in the number and prominence of state apologies to Indigenous peoples, coupled with debate among Indigenous peoples over the intent, sincerity, and outcome of these apologies, it is appropriate to assess the value of state apologies to Indigenous peoples in comparative perspective." (Why?)

In identifying and manipulating forms, we categorize ranked circumstances in relation to metaphorical and expanded circumstantial information. This delineation of form serves to clarify ranking circumstances, and more importantly, the meaning of the information in play. This provides a more comprehensive, inclusive approach to texts; in casting a broader analytical lens, we see more of the contextual information included and gain a better comprehension of meaning.

Table 3 shows an excerpt separated by clauses and connected to type of circumstantial information through probe questions. The form of the circumstantial information in the clause is indicated in superscript as follows:

1. ranking circumstances

2. hypotactic non-finite dependent clauses

3. post-modifying prepositional phrases within larger nominal groups

We point out how in 2, 4, and 7 the multiple probe questions indicate cascading post-modification, and confirm the focus of the additional information (head noun or process). This approach risks labeling almost anything as circumstantial information. However, at this point we are tasking the students with answering specific probe questions, not doing an analysis of all potential circumstantial information that may be contained in an excerpt. Our subsequent tasks bring students' attention back to pragmatic application to their academic literacy and performance.

To practice their lexicogrammatical flexibility (in service to paraphrasing), students are tasked with rendering the circumstantial information into ranking circumstances in the form of prepositional phrases; first with dependent clauses:

using this new Indigenous-specific framework

then shifting the verb to preposition:

with this new Indigenous-specific framework

and finally paraphrasing the noun group within the prepositional phrase:

with Цames' (2008) Indigenous-informed criteria 
Table 3 Circumstantial Information Excerpt

\begin{tabular}{|c|c|c|c|}
\hline & Clause & Probe Question & $\begin{array}{c}\text { Circumstantial Information } \\
\text { Type }\end{array}$ \\
\hline 1 & $\begin{array}{l}\text { Given the notable recent increase in the number and } \\
\text { prominence of state apologies to Indigenous peoples }\end{array}$ & Why? & Cause: reason \\
\hline 2 & $\begin{array}{l}\text { coupled with debate }{ }^{2} \text { among Indigenous peoples over the } \\
\text { intent, sincerity, and outcome of these apologies }{ }^{3} \text {, }\end{array}$ & $\begin{array}{l}\text { Who/What with? and } \\
\text { Where? } \\
\text { What about? }\end{array}$ & $\begin{array}{l}\text { Accompaniment: In the company } \\
\text { of and } \\
\text { Place: point in place and } \\
\text { Matter: topic }\end{array}$ \\
\hline 3 & $\begin{array}{l}\text { it is appropriate to assess the value of state apologies to } \\
\text { Indigenous peoples in comparative perspective }{ }^{3} \text {. }\end{array}$ & In whose view? & Angle: viewpoint \\
\hline 4 & $\begin{array}{l}\text { In this article' I I will first build a normative framework } \\
\text { specifically for state apologies to Indigenous peoples }^{3} \text {, } \\
\text { based on meaningfulness }{ }^{2} \text {, }\end{array}$ & $\begin{array}{l}\text { Where? } \\
\text { What/who for? } \\
\text { What about? }\end{array}$ & $\begin{array}{l}\text { Cause: purpose } \\
\text { Matter: topic }\end{array}$ \\
\hline 5 & $\begin{array}{l}\text { building on an earlier taxonomy by Canadian political } \\
\text { scientist Matt James² that assessed the "authenticity" of } \\
\text { state apologies in general. }\end{array}$ & How? & Manner: means \\
\hline 6 & $\begin{array}{l}\text { Second, I will conduct a comparative assessment of } \\
\text { apologies offered by four English-speaking settler states } \\
\text { (the United States, Australia, Canada, and New Zealand) }\end{array}$ & & \\
\hline 7 & $\begin{array}{l}\text { using this new Indigenous-specific framework based on the } \\
\text { meaningfulness of apologies². }\end{array}$ & $\begin{array}{l}\text { By what means? What } \\
\text { instrument was used? } \\
\text { What about? }\end{array}$ & $\begin{array}{l}\text { Manner: means } \\
\text { Matter: topic }\end{array}$ \\
\hline
\end{tabular}

This formula for paraphrasing breaks down the otherwise nebulous process into manageable pieces through labelling the discrete components and the shifts they can make (Walsh Marr, 2019). It also demonstrates to students the underlying meaning that prepositions carry-a topic typically neglected.

Probe questions are useful as catalysts for both analyzing and drafting texts. For critical reading, probe questions serve to interrogate the type of contextual information manifest or missing from a text. The task of identifying what type of information is included is the first step. A further analytical task is to ask about circumstantial information that may be embedded, assumed, or omitted; referring to probe questions such as "When?", "Where?" and "What about?" can establish background information for a more comprehensive initial understanding. Deeper analysis can be facilitated by looking for "How ?", "Who for ?", "According to whom?", and "From which perspective?". When this type of circumstantial information is investigated, it can shed light on biases, enabling students' critical engagement with texts and facilitating their own writing. One task to aid in the development of these skills is to provide a text with only simple participants and processes and see what questions emerge; this helps students appreciate the role of contextual information that circumstances (and circumstantial information) typically provide. Another task is to give different groups of students the same image, but give each group a different writing prompt with circumstance probes typical of the genre. Thus, a description includes circumstances about time, duration, Location, Manner of occurrence, any tools or instruments involved, and comparison to other events; an explanation includes conditions, reasons and consequence of its occurrence; and a recommendation prompts students to include circumstantial information about the purpose and beneficiaries of those recommendations as well as consider various viewpoints on those recommendations (Tervit \& Walsh Marr, 2019). 
Probe questions can also be used as catalysts for text revision, as enhancement through meanings of location, manner, cause and contingency can be expressed either through conjunctions or circumstances. Using these probe questions to interrogate and revise a text "can be thought of as a 'next step' in developing circumstantial meanings" (Eggins, 2004, p.283), giving emerging writers scaffolds to consider what additional information could and should be incorporated. Prompting students to address particularly manner, cause, and contingency facilitates a more comprehensive, satisfying text.

\section{Conclusion: Finally}

In this paper, we have demonstrated how circumstances are useful teaching tools for academic writing across metafunctions and how they provide disciplinary-specific insight. We have shown how widening the definition of circumstantial meanings, after Dreyfus and Bennett (2017), to include clauses and post-modifiers helps clarify ranked circumstances for students as well as provide access to a greater array of manifestations of circumstantial meaning. We have also emphasized how circumstantial meanings provide tools for paraphrasing with grammatical metaphor and critical lenses for reading.

This research is built on our experiences as teachers, our engagement with the texts our students must read and write, and our own research. It is necessarily limited in scope to a highly embedded context, one which has enabled us to achieve greater depth and breadth than circumstances are often afforded. The next step is to focus more research on the use of circumstances in a greater range of texts as well as develop more fully articulate pedagogical examples and teaching materials for teachers for enhanced praxis.

This paper provides a starting point for both researchers and teachers to more fully explore circumstances in different areas of discourse, in language and writing classes, and in research and teaching materials. Circumstances have thus far been under-recognized for their versatility, and we argue that they indeed merit some pomp and ceremony in the following circumstances: in research and in the classroom, across the disciplines, in speech and writing, and for teachers and students.

\section{References}

Alexander, O. (2019). The contribution of Halliday to EAP writing instruction: A personal journey. Journal of English for Academic Purposes, 41, 100769. https:// doi.org/10.1016/j.jeap.2019.100769

Andrea, A., \& Overfield, J. (2012). The human record: Sources of global history, Vol II: Since 1500. Wadsworth, Cengage Learning.

Banks, D. (2019). A systemic functional grammar of English: A simple introduction. Routledge. https://doi. org/10.4324/9780429467844

Butt, D., Fahey, S., Feez, S., Spinks, S., \& Yallop, C. (2000). Using functional grammar: An explorer's guide (2nd Ed.). National Centre for English Language Teaching and Research, Macquarie University.

Chen, S. K. (2016). Circumstantiation of projection: Functional syntax of Angle in English and Chinese. Ampersand, 3, 71-82. https://doi.org/10.1016/j. amper.2016.05.002

Derewianka, B. (2011). A new grammar companion for teachers (2 $2^{\text {nd }}$ Ed.). Primary English Teaching Association Australia.

Dreyfus, S., \& Bennett, I. (2017). Circumstantiation: Taking a broader look at circumstantial meanings. Functional Linguistics, 4(1), 5. https://doi.org/10.1186/ s40554-016-0036-y

Dreyfus, S., \& Hao, J. (2020). A multi-stratal perspective on circumstantial meaning. Journal of World Languages, 6(1-2), 1-19. https://doi.org/10.1080/216982 52.2020 .1720159

Dreyfus, S., \& Jones, P.(2008). Making sense of place: Further descriptions of Circumstance of location. In Proceedings of ISFC 35: Voices Around the World (pp. 1-6). Macquarie University.

Eggins, S. (2004). An introduction to systemic functional linguistics ( $2^{\text {nd }} \mathrm{Ed}$.). Continuum.

Fisher, R. (1992). Judging history: Reflections on the reasons for judgment in Delgamuukw v. B.C. BC Studies, 95, 43-54.

Halliday, M. A. K., \& Matthiessen, C. M. I. M. (1999). Construing experience through meaning: A language- 
based approach to cognition. (R. Fawcett, Ed.), Open Linguistics Series. Continuum.

Halliday, M. A. K., \& Matthiessen, C. M. I. M. (2014). Halliday's introduction to functional grammar ( $4^{\text {th }}$ Ed.). Routledge. https://doi. org/10.4324/9780203783771

Hood, S. (2010). Appraising research: Evaluation in academic writing. Springer. https://doi. org/10.1057/9780230274662

Humphrey, S., Droga, L., \& Feez, S. (2012). Grammar and meaning. Primary English Teaching Association Australia.

James, M. (2008). Wrestling with the past: Apologies, quasi-apologies, and non-apologies in Canada. In $\mathrm{M}$. Gibney, R. E. Howard-Hassmann, J.-M. Coicaud, \& N. Steine (Eds.), The age of apology: Facing up to the past (pp. 137-153). University of Pennsylvania Press.

The Learning Centre, The University of Sydney. (2012) WRiSE - Write reports in science and engineering. http://learningcentre.usyd.edu.au/wrise/home.html

Knox, P. L., \& Marston, S. A. (2013). Human geography: Places and regions in global context. Pearson.

Liardét, C.L.(2018). 'Aswe all know': Examining Chinese EFL learners' use of interpersonal grammatical metaphor in academic writing. English for Specific Purposes, 50, 64-80. https://doi.org/10.1016/j.esp.2017.11.005

Lightfoot, S. R. (2010). Emerging international indigenous rights norms and 'over-compliance' in New Zealand and Canada. Political Science, 62(1), 84-104. https://doi.org/10.1177/0032318710370584

Lightfoot, S. (2015). Settler-state apologies to Indigenous peoples: A normative framework and comparative assessment. Journal of the Native American and Indigenous Studies Association, 2(1), 15-39. https:// doi.org/10.5749/natiindistudj.2.1.0015

Martin, J. R., Matthiessen, C. M. I. M., \& Painter, C. (2010). Deploying functional grammar. (J. J. Webster, Ed.). Commercial Press.
Martin, J. R., \& White, P. R. R., (2005). The language of evaluation: Appraisal in English. Palgrave MacMillan.

O'Leary, A. (2019). LLED 201 SCI DA A1 Research Plan model (Unpublished teaching materials). UBC Vantage College.

Scott, D. C. Deputy Superintendent General of Indian Affairs. Testimony before the Special Committee of the House of Commons examining the Indian Act amendments of 1920. National Archives of Canada, RG, 10.

Tervit, T. \& Walsh Marr, J., (2019). LLED 200 Arts Week 10: Circumstances. (Unpublished teaching materials). uBC Vantage College.

Thompson, G. (2014). Introducing functional grammar ( $3^{\text {rd }}$ Ed.). Routledge. https://doi. org/10.4324/9780203785270

Truth and Reconciliation Commission of Canada. (2015). Introduction. Honouring the truth, reconciling for the future: Summary of the final report of the Truth and Reconciliation Commission of Canada (pp.1-26). http://www.trc.ca/websites/ trcinstitution/File/2015/Findings/Exec_Summary_2015_05_31_web_o.pdf

Walsh Marr, J. (2019). Making the mechanics of paraphrasing more explicit through grammatical metaphor. Journal of English for Academic Purposes, 42, 100783. https://doi.org/10.1016/j.jeap.2019.100783

Walsh Marr, J. (2020). vaNT 140 Arts Week 17: Participants and circumstances for evaluation. (Unpublished teaching materials). UBC Vantage College.

Wotherspoon, T., \& Hansen, J. (2013). The "Idle No More" movement: Paradoxes of First Nations inclusion in the Canadian context. Social Inclusion, 1(1), 21-36. https://doi.org/10.17645/si.v1i1.107

Young, I. M. (2013). Five faces of oppression. In J. De Filippis \& S. Saegert (Eds.), The community development reader (pp.346-355). Routledge. https://doi. org/10.4324/9780203935569

How to cite this article: Walsh Marr, J. \& Martin, J. L. (2021). Pomp and circumstances: From research, in practice, for students. Íkala, Revista de Lenguajey Cultura, 26(1), 227-242. https://doi.org/10.17533/ udea.ikala.v26n01a03 